DOI: 10.14807/ijmp.v12i9.1652

\title{
UNDERUTILIZATION OF WORKERS: AN ANALYSIS ACCORDING TO THE LEAN MANAGEMENT PHILOSOPHY IN BASIC EDUCATION
}

\author{
Alberto Eduardo Besser Freitag \\ Candido Mendes University, Brazil \\ E-mail: alberto.besser@professor.ucam.edu.br \\ Alexandre Barreto de Oliveira \\ Candido Mendes University, Brazil \\ E-mail: alexandre.oliveira@lasalle.org.br
}

Submission: 4/4/2021

Revision: 8/20/2021

Accept: 11/15/2021

\section{ABSTRACT}

One of the eight wastes that Lean production, inspired by the Toyota Production System, proposes to study is the underutilization of workers, that is, the inadequate use of their intelligence. The sense is to provide listening and participation in improvement projects, of professionals who have experience in daily life and, in many cases, consistent academic qualifications. The objective of this work is to study the importance of the participation of teachers and employees of a basic education school in the construction of new routines and work methods, in the context of the Lean management philosophy, justified by the scarcity of scientific literature on the subject. Brazil has about 184,000 basic education schools with one million four hundred thousand teachers working from kindergarten to the ninth grade of elementary school, and of these, $83.2 \%$ have a college degree, a percentage that grows every year. About the schools, $21.7 \%$ are private, $61.3 \%$ municipal, $16.6 \%$ state, and $0.4 \%$ are federal schools. As a research methodology, a systematic review of the literature was adopted, based on the PRISMA protocol, allowing the identification of 53 records, 14 of which were included in the literature review, due to their adherence to the researched subject. The main contribution of this paper is the identification of a research gap involving the underutilization of workers and adoption of the Lean management philosophy in the education 
INDEPENDENT JOURNAL OF MANAGEMENT \& PRODUCTION (IJM\&P)

http://www.ijmp.jor.br

v. 12, n. 9, Special Edition, December 21, IFLOG 2020

ISSN: 2236-269X

DOI: 10.14807/ijmp.v12i9.1652

sector, as well as a conceptual proposal of the positive impact on the educational organization results by not underutilizing workers, without wasting their intelligence.

Keywords: underutilization of workers; production; management; lean in education

\section{INTRODUCTION}

In Brazil, according to the latest School Census (MEC, 2017), there are about 184,000 basic education schools, $21.7 \%$ are private, $61.3 \%$ municipal, $16.6 \%$ state, and $0.4 \%$ federal schools. Of this total, $15.9 \%$ are called "large schools" because they have more than 500 students enrolled. On the other side, with $22.7 \%$ of the total, are the schools called "small" because they have a maximum of 50 students. And the other $61.40 \%$ correspond to schools that have between 51 and 499 students.

The country has about one million four hundred thousand teachers working from kindergarten to the ninth grade of elementary school, and of these, $83.2 \%$ have a college degree, a percentage that grows every year. Much is said about the teacher's role, and many conceptions of the teaching work are disseminated, implicitly or explicitly, in the school setting, in educational projects, in the management of educational systems, in institutions that train educators and researchers in the educational field, in educational reforms, in theoretical production, etc.

Given the need for teacher training and its importance for the development of the student, and the achievement of the goals and guidelines of private educational institutions, it is necessary to introduce these professionals in the conception of the institution's projects, by collecting their respective opinions and understanding of the routines, tasks and objectives. These are intellectual assets that cannot be restricted to the classroom.

It is possible to be concomitant in their routines and new doings, states Secchi (2009), who argues that it is more appropriate to speak of an accumulative process of changes in the practices and values of organizational models, rather than in the rise, predominance and decline of one or another model. Considering that each business model or action represents the set of administrative methods executed by the management of an organization to achieve its defined goals, such methods tend to change according to the peculiar characteristics of each organization (Silva, 2013).

With the increasing need for specialized and well-structured education, which must meet the desires of society, educational institutions have to become more competitive and 
DOI: 10.14807/ijmp.v12i9.1652

readjust, rectify, their management model whenever possible and necessary. Thus, in view of the necessity to adopt practices and concepts that value and listen to teachers, involving them in management, the concept of the Lean management philosophy emerges in administrative services, specifically with regard to administrative services in educational institutions. Its goal is to eliminate unnecessary steps and activities that overload employees, and do not add value in processes that should benefit students, schools and other participants, but also, and in this study, mainly, to appreciate the intellectual value of the professional (Silva, 2013)

With the Lean management philosophy, it is necessary to restructure the management concepts through practices based on continuous improvement, ensuring the quality and efficiency of the provided services, using as a reference the management administration model, because it contains tools whose purpose is the efficiency of procedures.

Considering the aforementioned, the problem of this research is to observe whether the Lean management philosophy is suitable for a social enterprise, more specifically a Basic Education Institution. Thus, it is important for academics to reflect and exercise on the evaluation of a management philosophy first created for the automobile industry, but now widely adopted and usable in all fields of activity.

In order to characterize the development of this article, the following research questions were identified:

- What is the contribution of the Lean management philosophy to the management of academic administrative processes in a Basic Education Institution?

- How the Lean Philosophy is applicable to a Basic Education Institution?

- Is it possible, through the application of the Lean philosophy, to establish points of improvement for an educational institution, regarding the better intellectual use of its teachers?

This study is justified by the challenges Brazil faces in education and by the country's need to maximize the resources (technical, financial, and human) available for this sector. Based on what was previously presented, this study has as objective the applicability of the Lean management philosophy in the school environment, more precisely in the pedagogical and administrative construction processes that take place there. It is intended to evaluate a basic education institution according to the 8th waste of the Lean management philosophy, the "Underutilization of Workers", that is, not making the best use of their intelligence. 
The method used in this study is based on a systematic review of the scientific literature, through the use of the PRISMA protocol, in four phases, in order to answer the proposed research questions. Fourteen studies were identified that cover, totally or partially, the approached theme. In addition to the academic literature, it was used research from websites, articles, reports, and the experience of one of the authors in his daily school life.

The structure of the sections of this paper begins with this introduction, which describes the characteristics of the education sector and the suggested problem. Next, the literature review is exposed, which serves as a background for the present article and as a complement to it in view of the experience in basic education and the particularities perceived by one of the authors in the educational sector. The chosen research methodology is the literature review, detailed in the third section.

In the sequence, the results and discussion deal with the contribution of the Lean philosophy to the management of academic administrative processes in a Basic Education Institution. The conclusion shows the need for the implementation of the Lean philosophy in basic education schools, in view of the possibility of using the intellectual capacity of teachers to solve problems and build teaching/learning methodologies that guide the school, as well as the considerable loss with the non-use of it.

\section{LITERATURE REVIEW}

The purpose of this article is to study the effectiveness of the Lean Management philosophy in an elementary school. This section begins with a literature review on the Toyota Production System (STP), whose main guidelines gave rise to the Lean management philosophy. After a brief explanation of the constitution of Basic Education in Brazil, it discusses the Lean management philosophy in Basic Education, addressing the waste of Underutilization of Workers, i.e., not making adequate use of their intelligence.

\subsection{Lean Management}

Lean management is articulated through four integrated disciplines: Connecting strategy, goals and meaningful purpose; Discovering better ways of working; Delivering value efficiently for the customer and; Enabling people to lead and contribute to their full potential (Jacquemont, 2014). The concept consists of using the necessary resources for the accomplishment of a certain work, stage or process, avoiding waste.

The use of this philosophy brings benefits when applied to business management, because it minimizes waste on several fronts (Lib, 2020). By following the principles of the 
DOI: 10.14807/ijmp.v12i9.1652

Lean management philosophy, leaders and managers can benefit by using employees' time and increase the productivity of their teams and sectors with actions such as:

- Constantly identify and eliminate problems that can hinder or slow down processes: New processes show knowledge and skills gaps, creating focused opportunities to develop the knowledge and skills of the people involved with the work;

- Ensure clarity in the workflow, making it possible to eliminate confusion or misunderstandings in communication: In addition to ensure that all processes generate value for the customer, they need to be organized in a flow of activities that enhance this element, which includes all activities performed in the company, from the most basic to the most strategic, seeking reorganization so that the focus is on creating value;

- Indicate priorities in the company's workflow: Key concept, because any kind of waiting is a waste. Its goal is to ensure delivery from the moment the order is received, until the moment it is delivered to the customer;

- Guarantee what is necessary for the team, so that they can, with quality, deliver on time and generate value for the customer: This is the first principle of this philosophy and is related to the value that the product creates for the customers, meaning that all processes must always be directed to generate value for the customers, according to their needs and demands.

In the early 1970s, the management practices adopted by Japanese companies, especially Toyota, started to be pointed out as the explanation for the success of the Japanese automobile industry at that time. Executives and researchers from Western countries traveled to Japan to visit Toyota and other companies and to learn about their management practices. In the 1980s Japanese automakers made direct investments alone or through joint ventures in the USA and Europe. These investments helped to overturn the belief that Japanese management practices would not be transferable to other cultural contexts (Hiraoka, 1989) and, according to Smith (2006), made worker participation part of the North American management objective.

These factors strengthened the management model, which became representative in what Powell (1991) and Dimaggio and Powell (2005) calls "isomorphism", which consists of a tendency of behavior in organizations to converge, in the sense of adopting practices that have wide acceptance or practices already institutionalized. The technological and economic 
environment, as well as the social and cultural environment, influence organizations to act in this way.

Meyer and Rowan (1991) argue that the adoption of practices already employed in some companies, demonstrates an appropriate behavior and protects those who adopt them from possible questioning. The organization is seen as legitimate in its environment, increasing the commitment of employees and stakeholders, which improves its conditions of survival, and makes that, at a certain point, its adoption becomes necessary to legitimize organizations and managers, regardless of the improvement it may bring to the performance.

Due to Lean production, there were signs of significant changes in the organization of work. The literature highlights the need for changes in the division and content of work, with expanded assignments for employees, who should be flexible to perform a wide variety of tasks, make decisions, solve problems, control quality, and perform continuous improvement.

The great relevance of the Lean management philosophy is not only in the implementation of methodologies and tools, but also in the change and maturing of the corporate culture, with greater involvement from the employees, which can generate greater operational development in dealing with problems, because it is possible to anticipate them when the routine is treated aiming at the continuous improvement of actions. When there is no continuous development, the time spent on "putting out fires" of the operational day-today is much longer, as shown in Figure 1.

\begin{tabular}{||c|c|c|c||}
\hline $\begin{array}{c}\text { Traditional } \\
\text { management }\end{array}$ & \multicolumn{2}{|c||}{$40 \%$} & $\begin{array}{c}60 \% \\
\text { Day-to-day operation }\end{array}$ \\
\hline \multirow{2}{*}{ Lean management } & $\begin{array}{c}20 \% \\
\text { Day-to-day } \\
\text { operation }\end{array}$ & $\begin{array}{c}20 \% \\
\text { Putting out } \\
\text { fires }\end{array}$ & Continuous improvement and innovation \\
\hline & \multicolumn{2}{|c|}{ Routine } & Working with multi-functional teams \\
\hline
\end{tabular}

Figure 1: Traditional Management vs. Lean Management Source: Adapted from Kacar (2017)

\subsection{Basic Education}

Basic education corresponds to the first educational stage and aims at the citizenship formation of young Brazilians. To this end, it is divided into stages, each with distinct 
objectives. They are organized in different ways, with their own characteristics and philosophies.

The three major stages are: early childhood education, elementary school and high school. According to the Law of Guidelines and Baselines for National Education (Law 9.394/96) (LDB, 1996), basic education is compulsory from the age of four. The State is responsible for legislating and authorizing private schooling, as long as the conditions established in the legislation are met.

The Common National Curricular Baseline (BNCC, 2018) is the document that guides educators and educational institutions on the knowledge considered essential and indispensable to the development of children and youth. The BNCC (2018) proposes strategies, concepts, and situations that should be addressed at each stage of basic education, such as the general competencies of early childhood education.

Early childhood education is for children from zero to five years of age. At this stage, the first contact with school takes place, and it is a fundamental phase for the global development of the students, especially regarding socialization with other children and families. In early childhood education, the cognitive, physical, motor, psychological, cultural, and social aspects of the students are stimulated, always through playful activities that enable their imagination and creativity (RCNEI, 2010).

Elementary school with a total duration of nine years is the stage of basic education that prepares students to be proficient in reading, writing, and arithmetic, in addition to enabling them to understand the social environment in which they are inserted and its nuances. This is subdivided into the initial years, 1 st to 5th grade, and it is the time dedicated to the school introduction of educational concepts that will be present throughout basic education, as well as the beginning of the literacy process; and the final years, the period formed by the 6th to the 9th grade and presents the student with more complex learning challenges, in addition to increasing the repertoire of knowledge and content. At this time, issues of independence and responsibility are also explored (PCN, 1997).

High school is associated with the preparation of young people for ENEM (National High School Exam) and other college entrance examinations. During this school stage, students work on self-knowledge, intellectual autonomy, and critical thinking, among others. Finishing high school is crucial for placing young people in the job market, and a requirement for entering the country's universities (PCN, 1997). 
DOI: 10.14807/ijmp.v12i9.1652

There is a question that underlies all discussions involving school management. What makes a school successful? Although acting in the most diverse states and cities of the federation, the question has a tendency to be answered, which would be: the pedagogical proposal, collectively built and materialized through a good planning, and under a rigorous management system. The pedagogical proposal, pedagogical project, political pedagogical project (PPP) or educational project, is the school's identity, because it establishes the basic guidelines and the direction of teaching and performance in the school community.

It formalizes and identifies the commitment made by teachers, employees, managers, representatives of parents and students, and community leaders around the same educational project. Planning is the action plan that, in a given period, will lead the school to achieve its goals and objectives. From planning come lesson plans, which will be adapted to the daily routine of the classroom.

"The project represents the opportunity for the board, the pedagogical coordination, the teachers, and the community to take their school in hand, define its strategic role in the education of children and young people, and organize its actions to achieve the proposed objectives. It is the organizer, the guide of school life" (Libâneo, 2002, p. 96).

The LDB (1996) establishes that the pedagogical proposal is a reference document. Through it, the school community exercises its financial, administrative and pedagogical autonomy. A "small constitution", according to Spanish educator Manuel Álvarez. Developing or preparing this document is an opportunity for the school to choose the curriculum and organize space and time according to teaching needs and possibilities. Besides the LDB (1996), the pedagogical proposal must consider the guidelines contained in the curriculum guidelines prepared by the National Education Council (CNE) and in the PCN (1997).

The pedagogical proposal must be built and developed involving all the professionals who work directly with or through the document

"providing spaces for each of the parties to expose their objectives and interests based on the educational principles with which everyone agrees" (Álvarez, 2004).

“(...) which it is the clarifying instrument of educational action of the school as a whole and its purpose is to guide the pedagogical actions. The political-pedagogical project is conceived as the theoreticalmethodological instrument that the school elaborates, in a participatory way, with the purpose of indicating the direction and the 
path it will take to accomplish, in the best possible way, its educational function" (Veiga, 1998).

Why a Political Pedagogical Project?

Project, because it gathers concrete action proposals to be executed during a certain period of time and it is constantly under construction.

Political, because it considers the school as a space for the formation of conscious, responsible, and critical citizens, who will act individually and collectively in society, changing the directions it will take.

Pedagogical, because it defines and organizes the activities and educational projects required for the teaching and learning process, and concerns to the systematic reflection on the educational practices.

\subsection{Lean Philosophy and Basic Education}

The development of a nation is totally dependent on the quality of the educational system, according to Tofte (1995). The first steps in the application of Lean thinking in an educational institution were in private education (Flumerfelt, 2008). These institutions dedicated all the necessary resources to support the initiatives for the development of this philosophy.

In the quality aspect, Lean management can be tied to providing students with challenging teaching and personalized situations, meeting their needs, interests, and expectations, in the search for continuous improvement in customer satisfaction processes, adding value to life. When the student does not have a sense of what he or she needs to learn and how to learn it, the teacher becomes more relevant, as he or she must understand these needs and cross-reference them with the needs of future employers. An important factor of the Lean management philosophy in a school of basic education is the benefit for all stakeholders, as it analyzes the entire system in detail and develops solutions with the help of employees, always striving for continuous improvement.

Regarding organizational culture, Bergman (1995) explains that educational institutions have a very deep-rooted culture so that employees devote all their time to the institution. The author concludes that by applying Lean thinking to educational services, the schools improve their operations and the expected program results. The same author reports that by implementing this way of working, the organization gains a proactive attitude, enabling greater involvement in improving student learning processes. 
DOI: 10.14807/ijmp.v12i9.1652

Two fundamental concepts arise with these principles: respect for each individual and leadership based on humility, which according to Engelen (2014) suggests the existence of an environment that encourages ideal employee behavior, that helps employees when there is a deviation from behavioral. The author also exposes that respect should also be applied with customers, suppliers, community, and society.

The other guiding principle shows that the leader needs to know how to listen and learn continuously, thus creating a respectful environment, making his employees use all their creative abilities.

"Leadership is the ability to influence people to work enthusiastically toward goals identified as being for the common good” (Hunter, 2004).

As mentioned previously, the Pedagogical Proposal is the guiding document of the educational community. When this is developed from the standpoint of the participation of collaborators in the creation, development, training, implementation and follow-up, the objectives to be reached will become more enjoyable and more likely to be achieved.

To waste the intellectual capacity and abilities of employees that are sometimes treated as robots, programmed only to do a certain function, is not interesting for the process. Encouraging the human intellectual is one of the great strategies for professional motivation. It is the manager's role to identify the most suitable activities for each worker, and always try to motivate and develop the workers. The school will gain a lot in results when these professionals are motivated and encouraged to propose ideas.

\section{RESEARCH METHODOLOGY}

Scientific research is an essential activity in science (Silveira \& Córdova, 2009), through which the purpose is to reach a better understanding of a certain reality that one wishes to investigate (Silva, 2005). The reason for the emphasis on the methodology used in a research is justified by the need for an adequate scientific foundation, aiming for the best approach to clarify the research questions (Miguel, 2010). According to Gil (2010), the methodology concerns to the entire research planning, covering from its elaboration to the prevision of data analysis and interpretation.

Regarding the nature of a research, the criteria for classifying the types of research vary from author to author, following interests, objectives and fields. Ander-Egg (1978) classifies the nature into two types: pure basic or fundamental research, which seeks scientific 
DOI: 10.14807/ijmp.v12i9.1652

progress and aims at knowledge for knowledge's sake, and applied research which, as the name implies, has practical interests in solving problems.

When the solution to a research problem has no apparent application to a practical problem, such research is called "pure" rather than "applied" (Booth, Colomb \& Williams, 2019). Based on the above, the nature of this research can be classified as applied, considering that the presented conceptual proposal aims to encourage the use of the Lean management philosophy in an educational context, specifically avoiding the 8th waste - the underutilization of workers, that is, the inadequate use of their intellect.

The strategy for collecting information was the bibliographic research, defined by Gil (2002) as a compilation consisting mainly of books and scientific articles. Its purpose is to analyze different positions that encompass a given subject. Marconi and Lakatos (2003) also state that such research is based on important works carried out with the capacity to enrich the material.

The studies were collected throughout the month of October 2020 in the databases Scielo and Capes Journals Website (search subject). The Scielo database was chosen because it is intended to "implement an electronic library that can provide broad access to journal collections as a whole, to the issues of each journal title, as well as to the full texts of articles." The Capes Journals Website (search subject) "is a virtual library that gathers and makes available to teaching and research institutions in Brazil the best of international scientific production. It has a collection of more than 45 thousand titles with full text, 130 referential bases, 12 bases dedicated exclusively to patents, besides books, encyclopedias and reference works, technical norms, statistics and audiovisual content."

The research process involved a systematic literature review using the PRISMA protocol (Moher et al., 2009). A literature review fulfills several purposes, among them, it shares with the reader the results of other studies that are closely related to the one being conducted, fills gaps by expanding previous studies, and provides a framework for establishing the importance of the study and also a reference for comparing the results with other findings (Creswell, 2010).

In Robson's (2011) view, a systematic literature review is a specific way of identifying and synthesizing the evidence of a research study, with emphasis on:

- Provide comprehensive coverage of the available literature in the field of interest studied; 
DOI: $10.14807 /$ ijmp.v12i9.1652

- Quality of the reviewed evidence presented;

- Follow detailed and explicit approach to data synthesis; and

- Use of transparent and rigorous processes throughout the conducted researches.

The systematic literature review was divided into four phases, as follows: 1) Identification of records - in Scielo and Capes Journals Website (subject search), 2) Screening - by excluding duplicated records, 3) Eligibility - by excluding unavailable text, method or author, and 4) Inclusion - by excluding documents not aligned with the purpose of this study. To search for records in the databases, the search phrase and boolean operators (lean AND "basic education") were used.

The search phrase was defined based on the professional experience of one of the authors, who holds a management position in a Basic Education Institution, as well as through preliminary research with a few articles, from which the most repeated terms were selected. It was decided to apply filters to the search engines in the scientific databases, allowing the identification only of articles between the years 2015 and 2020, because when removing this filter, the number of records is very extensive and almost all of them are not aligned with the subject of this research.

\section{RESULTS ANALYSIS AND DISCUSSION}

\subsection{Literature Review Results}

Table 1 shows the results of the systematic literature review, along the four phases of the PRISMA protocol (Moher et al., 2009).

In the Scielo database, the search phrase (lean AND "basic education”) returned 33 records, but following the elimination criteria in the screening, eligibility and inclusion phases, 14 records were used for this research.

In the Capes Journals Website (subject search), the search phrase (lean AND "basic education”) returned 20 records, but following the elimination criteria in the screening, eligibility, and inclusion phases, no records were used for this research.

The 53 records were selected for analysis in the second phase, and the same number was maintained, due to the fact that there were no duplicate records. In the third phase, three records were excluded, whose documents had no information about the authors or were not available in the scientific databases searched, even after subsequent searches in Google Scholar, Research Gate, or free sites for scientific articles. 
INDEPENDENT JOURNAL OF MANAGEMENT \& PRODUCTION (IJM\&P)

http://www.ijmp.jor.br

v. 12, n. 9, Special Edition, December 21, IFLOG 2020

ISSN: 2236-269X

DOI: 10.14807/ijmp.v12i9.1652

Table 1: Information flow through the phases of a systematic literature review

\begin{tabular}{|c|c|c|c|c|c|}
\hline $\begin{array}{l}\text { Scientific } \\
\text { database }\end{array}$ & Search phrase & $\begin{array}{l}1 . \\
\text { Identification }\end{array}$ & 2.Screening & 3.Elegibility & 4.Inclusion \\
\hline \multirow{5}{*}{$\begin{array}{l}\text { Scielo } \\
\text { Capes } \\
\text { Journals } \\
\text { Website }\end{array}$} & & $\begin{array}{l}\text { Exclusion } \\
\text { Criteria }\end{array}$ & $\begin{array}{l}\text { Duplicated } \\
\text { records (\#0) }\end{array}$ & $\begin{array}{l}\text { Text, authors or } \\
\text { method not } \\
\text { available (\#3) }\end{array}$ & $\begin{array}{l}\text { Texts not aligned } \\
\text { with the scope of this } \\
\text { study (\#36) }\end{array}$ \\
\hline & $\begin{array}{l}\text { lean AND } \\
\text { "basic } \\
\text { education" }\end{array}$ & 33 & 33 & arancore (mo) & 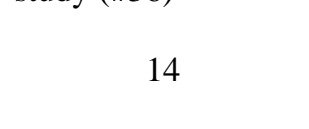 \\
\hline & lean AND & & & & \\
\hline & $\begin{array}{l}\text { "basic } \\
\text { education" }\end{array}$ & 20 & 20 & 20 & 0 \\
\hline & Total & 53 & 53 & 50 & 14 \\
\hline
\end{tabular}

This left 50 records, which were used for the fourth phase, in which 36 articles that were not totally or partially aligned with the scope of the study were eliminated. Therefore, 14 articles that were totally or partially aligned with the proposed study were included in the qualitative overview and the literature review. Table 2 displays the main topics that were identified, with their respective references.

\subsection{Qualitative Overview}

When analyzing the documents included in the literature review, it was evidenced that:

- Year: the first study dates back to 2015 and the most recent to 2019. There were studies in the years 2016, 2017, and 2018. In the years 2015 and 2017, five studies were published per year. In the years 2016, 2018 and 2019, only one study. It can be seen that interest in the subject emerged in this decade, so it is relatively recent and there is potential to be explored in the theme involving Lean management, tied to education;

Table 2: Topics and references

\begin{tabular}{ll}
\hline \multicolumn{1}{c}{ Topics } & \multicolumn{1}{c}{ References (year) } \\
\hline Lean Management & $\begin{array}{l}\text { LIB (2020), Jacquemont (2014), Hiraoka (1989), Smith (2006), Powell } \\
\text { (1991), Dimaggio and Powell (2005), Meyer and Rowan (1991), Kacar } \\
\text { (2017) } \\
\text { LDB (1996), BNCC (2018), RCNEI (2010), PCN (1997), Libâneo (2002), } \\
\text { Álvarez (2004), Veiga (1998) }\end{array}$ \\
$\begin{array}{l}\text { Lean Phic Education } \\
\text { Education }\end{array}$ & \multicolumn{1}{c}{ Source: The authors (2021) } \\
\hline
\end{tabular}

- References: few authors of the studies are repeated, revealing that there is space for a researcher interested in the relationship between Lean management and the subject of education to stand out in this field of research; 
- Institutional affiliation: similarly to the references, there is also no institution that stands out in the subject. In Brazil, the only institution identified with research and implementation of Lean in the service sector is the Federal University of Santa Catarina (UFSC), which promotes updating courses and debates for the formation and development of the concept among employees;

- Countries: the countries of origin of the institutions cited are Brazilian and one Colombian. It is known that the theme is beginning in Brazil and Latin America, especially in the services area, where there are few publications;

- Source: similarly to the references, articles and institutional affiliation, there is no publication that stands out in research involving Lean management regarding the waste of Underutilized Workers;

- Method: among the various methods described, the highlight goes to the systematic review of the literature in the 14 studies.

In view of the analysis of the articles under investigation on the proposed theme, it is important to state that there is a negative impact when the school does not use or underuses its employees/workers in the organization's results, because they could contribute in an even more assertive way, due to their training and experience, in the construction of new processes and procedures, which would positively impact on the valorization of the professional and on the increase of the revenue, because it would lead to a greater decrease in organizational costs.

\subsection{Conceptual Proposal}

From the content analysis of the studies inserted in the literature review, it was possible to establish a conceptual proposal of the positive impact of the Lean management philosophy in educational institutions, specifically regarding the 8th waste - the underutilization of workers, i.e., the non-adequate use of their intellect (Figure 2).

This is one of the pillars of the Toyota Model: respect for the people who make the company progress, grow and develop; where leadership needs to be perceived playing a central role in developing the culture, teaching, inspiring to live the company's philosophy in their day to day actions, valuing listening and participation in the development of new processes and projects. 
DOI: 10.14807/ijmp.v12i9.1652

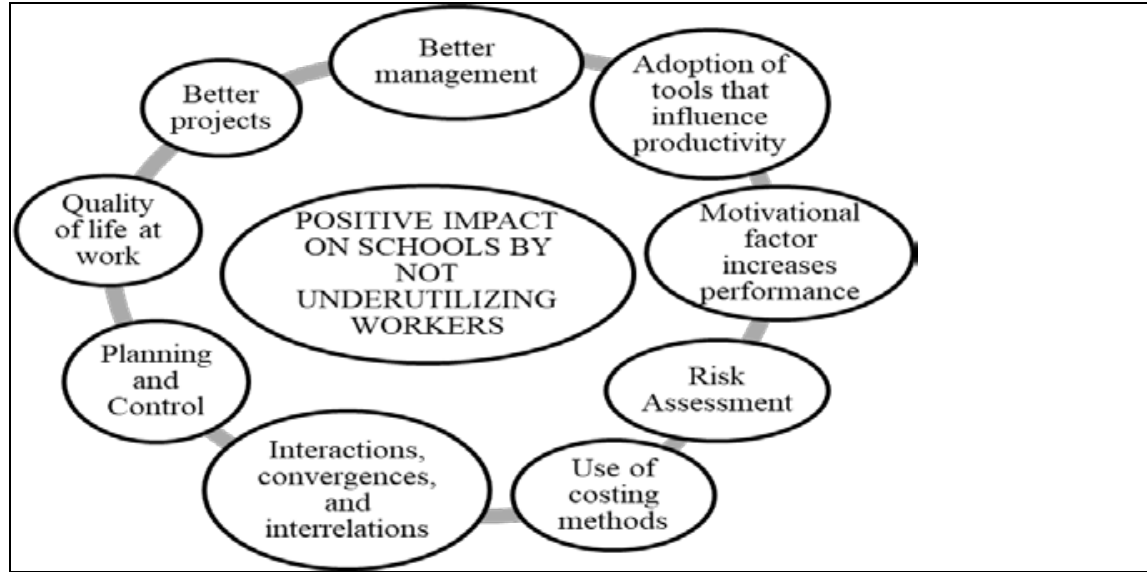

Figure 2 - Conceptual proposal of a positive impact on the results of educational institutions by not under-utilizing workers, without wasting their intellect.

Source: The authors (2021)

Leaders are perceived as masters from whom one learns the job and the internalization of culture (Liker, 2005). Companies that care about the valorization of their employees, as a form of listening and participation, and are more humanized, are also more productive and have happier, more satisfied and more committed employees with their personal, professional and corporate development. By valorizing, by giving voice to the employee, organizational growth is achieved. A valorized employee generates more satisfaction and increased productivity, because he feels part of the company, which will enable him to take more pleasure in performing his activity.

"People should be seen as partners of organizations. As such, they are suppliers of knowledge, skills, competencies and, above all, the most important contribution to organizations: the intelligence that provides rational decisions and gives meaning and direction to global objectives. And it is in this environment that employees share knowledge and develop their competencies" (Chiavenato, 2005, p.8).

It is possible to describe "values" as everything that is appreciated by human beings, regardless of whether it is treated as personal, professional, or organizational life. Human values have great importance in the development of the work environment, and valorized people give more visibility to the company, because they feel more involved and more committed to the organization, when they feel part of the company's growth and success. As stated by Chiavenato (2005), companies are fundamentally made up of intelligence, something that only people possess, and the capital will only be well applied when it is invested and managed in the same way.

There is a direct impact on school results when they underuse the intellect of their employees, because as described above, and in previous topics, teachers have a direct 
participation in the life and education of their students. Not being a relevant part of the organization's daily routine will lead to little engagement in the school's routine, which will be easily demonstrated in the development of school routines and in the teaching of classes.

And it is known that the final product of a school are the classes taught in the classrooms. A good example is the use of serious games development in elementary and high school classes, focusing on the students and teachers experiences from Brazilian scholar reality, as described by Júnior et al. (2020). The results obtained in experiments in public schools show successful acceptance and they contribute to improve the students' academic performance.

If the product delivered doesn't meet the consumer's expectations, as in the case of a private school, the possibility of renewal and continuity, by the families that hired the services, is very small. This will lead to a decrease in the number of students and a consequent drop in revenue from tuition payments, affecting the sustainability of the school.

It is essential for the organization to valorize each employee in his or her work sector, because they are the ones who give existence, growth, and results to the company. When the organization prioritizes this valorization, it not only improves and increases its results, but also gains employees who are committed, involved, respectful, and satisfied with their work. And people like that will be able to implement the processes needed for a continuous improvement program, described by Formento et al. (2013).

To maintain a healthy environment, it is necessary to maintain a company strengthened and grounded in the proper values. Therefore, it is essential to valorize each professional in his or her work environment, because without people to produce, innovate, create ideas, and generate synergy, there are no organizations; even more in a dynamic environment such as a school. Because of all these aspects, it is essential to valorize each employee in the company, in the school, because they are the ones who give life, productivity, and accurate results to the organization.

\section{CONCLUSIONS}

The Lean management philosophy is based on the Toyota Production System, which has as its guiding principles continuous improvement and respect for people. Despite this understanding, there is scarcity in the scientific literature about Lean management applied to the education sector and, especially, about the waste of Underutilization of Workers (not using their intellect properly), which justified the present study, whose objective was to study 
DOI: 10.14807/ijmp.v12i9.1652

the importance of valorizing the intelligence of employees, in the scope of participating in the elaboration of processes and methods in basic education schools.

As a method, a systematic literature review through the PRISMA protocol was adopted, with the identification of records in the scientific databases Scielo and Capes Journals Website (search subject), and their subsequent screening, eligibility and inclusion in the qualitative overview, in which 14 documents were included in the literature review section, being possible to answer the research question about the Underutilization of Workers, and how it can negatively impact organizations, especially those of education.

The objective of the research was achieved, since it allowed important thoughts about the Lean management philosophy in the educational sector, especially in basic education, the subject of this study. In universities, the teaching of Lean has a considerable level and is expanding, but in basic education there is little reference or interest in its implementation. In universities, the teaching of Lean is due to the companies' demand for academic content to guide the implementation, having as reference and evidence, the use in administrativeacademic processes and occasional experiences in learning processes.

Even though it is treated with much enthusiasm, under the perspective of continuous improvement, the Academy, especially schools, have not incorporated the Lean management philosophy to its full potential. In many cases this shows total ignorance of the power of transformation that can be provided through positive results in the generation of value from the learning process and employee engagement, because human engagement is necessary for its implementation to be successful.

The Lean management philosophy is not a magic formula, but a set of principles, values, and tools that can awaken the spirit of challenge and the desire for continuous improvement through the use of scientific methods to solve problems, such as innovation and talent management. And in this respect, valorizing the intellectual capacity of the employee allows the scientific method to be injected into the way one works, signifying and reaffirming its importance in monitoring the progress of projects, as opposed to simply evaluating the impact retroactively at completion.

A limitation of this study are the scientific databases researched, which did not consider worldwide bases such as Scopus and Web of Science, but this does not diminish the importance of the results found. For future research, it is suggested to verify the positive 
INDEPENDENT JOURNAL OF MANAGEMENT \& PRODUCTION (IJM\&P)

http://www.ijmp.jor.br

v. 12, n. 9, Special Edition, December 21, IFLOG 2020

ISSN: 2236-269X

DOI: 10.14807/ijmp.v12i9.1652

impact of the full use of employees' intelligence, as advocated by the Lean philosophy, in basic education schools, through a case study.

\section{CONFLICT OF INTEREST}

"We certify that there are no conflicts of interest associated with the work described in the article. All corporate or institutional affiliations and all sources of financial support to the research is properly cited or mentioned in the manuscript.”

\section{REFERENCES}

Álvarez, M. (2004). O Projeto Educativo da Escola, 180 págs., Ed. Artmed.

Ander-Egg, E. (1978). Introducción a las técnicas de investigación social: para trabajadores sociales. 7. ed. Buenos Aires: Humanitas.

Bergman, B. (1995). Quality in academic leadership: A contribution to the discussion. Total Quality Management, 6(5), 487-496.

BNCC. (2018). Base Nacional Comum Curricular. Available at:

http://basenacionalcomum.mec.gov.br. Accessed on: October 30, 2020.

Booth, W. C., Colomb, G. G., \& Williams, J. M. (2019). A arte da pesquisa. 3. ed. São

Paulo: Martins Fontes.

Chiavenato, I. (2005). Gerenciando com as Pessoas: transformando o executivo em um excelente gestor de pessoas. Rio de Janeiro: Elsevier.

Creswell, J. W. (2010). Projeto de pesquisa: métodos qualitativo, quantitativo e misto. 3. Ed. Porto Alegre: Artmed.

Dimaggio, P. J., \& Powell, W. W. (2005). A Gaiola de Ferro Revisitada: Isomorfismo Institucional e Racionalidade Coletiva nos Campos Organizacionais. Available at: http://bibliotecadigital.fgv.br/ojs/index.php/rae/article/viewFile/37123/35894. Acessed on: November 13, 2020.

Engelen, G. (2014). How can we respect every. Utah: Shingo Institute. Available at: http://shingo.org/blog/index.php/4-how-can-we-respect-every-individual. Acessed on: October 30, 2020.

Flumerfelt, S. (2008). Is lean appropriate for schools? Oakland: Pawley Learning Institute. Available at:

https://www.oakland.edu/upload/docs/Pawley/Lean\%20for\%20Schools/Whitepapers/WP_Le a n_Appropriate_for_Schools.pdf. Acessed on: October 30, 2020.

Formento, H. R., Chiodi, F. J., Cusolito, F. J., Altube, L. A., \& Gatti, S. P. (2013). Key factors for a continuous improvement process. Independent Journal of Management \& Production, 4(2).

Gil, A. C. (2002). Como elaborar projetos de pesquisa. Quarta edição. Editora Atlas.

Gil, A. C. (2010). Método e técnicas de pesquisa social. 6. ed. São Paulo: Atlas.

Hiraoka, L. (1989). Japanese automobile manufacturing in an American setting.

Technological Forecasting and Social Change, New York, 35(1), 29-49. 
Hunter, J. C. (2004). O Monge e o Executivo - uma história sobre a essência da liderança. Ed Sextante.

Jacquemont, D. (2014). The Lean Management Enterprise. A system for daily progress, meaningful purpose, and lasting value. McKinsey \& Company.

Júnior, W. M. F., Martinelli, S. R., Santos, C. H. S., \& Homem, M. R. P. (2020). Gamification based learning activities in elementary brazilian public schools. Independent Journal of Management \& Production, 11(6).

Kacar, D. U. (2017). Senior OPEX Implementer | Change Agent | Proactive Sustainable Management System Implementer, LinkedIn Group.

LDB - Lei de Diretrizes e Bases da Educação. (1996). Lei 9.934/96. Available at: http://www.planalto.gov.br/ccivil_03/leis/19394.htm. Acessed on: October 30, 2020.

LIB - Lean Institute Brasil. (2020). Quem Somos - O que é Lean. Available at: https://www.lean.org.br/. Acessed on: October 30, 2020.

Libâneo, J. C. (2002). Pedagogia e Pedagogos, para que?; 5a ed; São Paulo: Cortez.

Liker, J. K. (2005). O modelo Toyota: 14 princípios de gestão do maior fabricante do mundo. Porto Alegre: Bookman.

Marconi, M. De A., \&; Lakatos, E. M. (2003). Fundamentos de metodologia científica. 5. ed. São Paulo: Atlas.

MEC - Ministério da Educação e Cultura. (2017). Censo Escolar 2017. Available at: www.mec.gov.br. Acessed on: October 27, 2020.

Meyer, J. W., \& Rowan, B. (1991). Institutionalized organizations: formal structure as myth and ceremony. In: Powell W., \& Dimaggio P. (Eds.). The New Institutionalism in Organizational Analysis. Chicago: The University of Chicago Press, p. 41-62.

Miguel, P. A. C. (org.) (2010). Metodologia de pesquisa em engenharia de produção e gestão de operações. Rio de Janeiro: Elsevier.

Moher, D., Liberati, A., Tetzlaff, J., Altman, D. G., \& The Prisma Group. (2009). Preferred Reporting Items for Systematic Reviews and Meta-Analyses: The PRISMA Statement. PLoS Med, 6(7).

PCN. Parâmetros Curriculares Nacionais. (1997). Available at: http://portal.mec.gov.br. Acessed on: October 30, 2020.

Powell, W. W. (1991). Expanding the scope of institutional analysis. In: Powell, W. W., \& Dimaggio, P. The new institutionalism in organizational analysis. Chicago: The University of Chicago Press, 183-203.

RCNEI. (2010). Referencial Curricular Nacional para a Educação Infantil. Available at: http://portal.mec.gov.br. Acessed on: October 30, 2020.

Robson, C. (2011). Real World Research: a resource for users of social research methods in applied settings. 3rd Ed. West Sussex: John Wiley\& Sons, Ltd.

Secchi, L. (2009). Modelos Organizacionais e Reformas da Administração Pública. Revista de Administração Pública. Rio de Janeiro.

Silva, A. Do C. (2013). Evolução da administração pública no Brasil e tendências de novos modelos organizacionais. Cuiabá. Available at: 
https://www.passeidireto.com/arquivo/36751679/evolucao-da-administracao-publica-nobrasil-e-tendencias-de-novos-modelos-organi. Acessed on: November 12, 2020.

Silva, T. T. (2005). Documentos de Identidade: uma introdução às teorias do currículo. Belo Horizonte: Autêntica.

Silveira, D. T., \& Córdova, F. P. (2009). A pesquisa científica. In: Gerhart, Tatiana Engel; Silveira, Denise Tolfo. Métodos de pesquisa. Porto Alegre: Editora da UFRGS.

Smith, A. (2006). A Riqueza das Nações. São Paulo, Cap IX, p. 87.

Tofte, B. (1995). A theoretical model for implementation of total quality leadership in education. Total Quality Management, 6(5), 469-478.

Veiga, I. P. A. (1998). Perspectivas para reflexão em torno do projeto político pedagógico. In: Veiga, Ilma Passos A., \& Resende, Lúcia G. (orgs.). Escola: espaço do projeto político-pedagógico. Campinas, SP: Papirus. 